well as Mycoderma vini and cerevisiae. A short account is given of the history of fermentation and of the controversy respecting spontaneous generation. Then follow discussions of the biological relationships of yeasts, variations in the Saccharomycetes, morphology and anatomy of yeast-cells, spore-formation and its application to the analysis of yeasts, and a number of allied subjects. Lastly come descriptions of the more important culture and wild yeasts met with in the brewing, distilling, and wine-making industries.

The last chapter gives a brief account of the methods and apparatus employed in the preparation and transport of cultures of pure yeast for industrial purposes.

The translation has been on the whole well done, although in some cases the English is stiff and the grammar faulty. Rather ugly split infinitives occur in moderately large number, and subject and verb do not always agree in number. Use of the expression "equal molecules of dextrose and lævulose" is difficult to defend, and "sorbite," "mannite," and "albuminoid" are nowadays better termed "sorbitol," "mannitol," and "protein." Very few misprints are noticeable; $d$-methylglucoside (p. 359) obviously refers to $\alpha$-methylglucoside.

T. H. P.

\section{THE FISHES OF AFRICA.}

Catalogue of the Fresh-Water Fishes of Africa in the British Museum (Natural History). By G. A. Boulenger, F.R.S. Vol. ii. Pp. xii +529 . (London: British Museum (Natural History), I9II.) Price $2 l$. $5 s$.

THE author is to be heartily congratulated on the appearance of the second volume of this great work, which succeeds its predecessor after an interval of two years, a period by no means excessive when the amount of labour involved in a task of this nature is taken into consideration. The present volume completes the account of the carp tribe (Cyprinidæ), containing the great bulk of that group, and likewise includes the whole of the cat-fishes (Siluridæ), several new genera and species being named.

Although no one regards systematic works of this class as the final aim and end of zoological science, their importance and value cannot be overestimated, since it is upon such sure foundations that all superstructures of a more far-reaching and philosophical nature must be based. That it was high time the task of bringing our knowledge of the African Cyprinidæ and Siluridæ up to date was undertaken will be evident by a comparison of the number of species of certain groups recorded in the present volume with that given in Dr. Günther's "Study of Fishes," published in 1880 , and based on articles in the ninth edition of the "Encyclopædia Britannica." It is stated, for instances, in p. 573 of the "Study of Fishes" that the total number of species of cat-fishes of the exclusively African genus Synodontis is fifteen, whereas $\mathrm{Mr}$. Boulenger has swelled the list to fifty-seven. Again, Dr. Günther estimated the total number of representatives of the Old World cyprinoid genus Barbus at about 200, while Mr. Boulenger gives a list (inclusive of nine additional uncatalogued species) of no fewer than NO. 2 I75, VOL. 87$]$
I94 African members of the genus. Unfortunately comparisons cannot be extended to the total numbers of African Cyprinidæ and Siluridæ recorded by the two naturalists, as Dr. Günther enumerates only those inhabiting Africa south of the Sahara; but, even so, his lists of fifty-two Cyprinidæ and sixty-one Siluridæ (op. cit. p. 23o) inhabiting Ethiopian Africa are altogether outclassed by $\mathrm{Mr}$. Boulenger.

This great increase in the number of African representatives of the two families has, of course, a most important bearing on previous conclusions as to the place of origin of the two groups. Dr. Günther (op. cit. p. 225) suggested that since the majority of the groups of fresh-water fishes common to India and Africa, with the exception of the siluroid Clarias and its relatives, had more representatives in the former than in the latter area, the presumption is that they are of Asiatic origin. Although these conditions are now in many cases reversed, the conclusion will, we think, still hold good in the case of Barbus, the members of which, like many groups of antelopes with ancestral forms in India, would appear to have undergone an unparalleled development when they reached Africa. On the other hand, the abundance of siluroids in the Eocene of the Fayum, where no remains of cyprinoids have hitherto been discovered, points to the conclusion that this group is endemically African. And here it is noteworthy that the connection between the African and South American cat-fishes is now regarded as even less intimate than was the case when Dr. Günther's work was written, the two African species there referred (p. 233) to the South American Pimelodus now being assigned to a genus apart. But to pursue this interesting subject would demand more space than can be given to it in these columns.

If such space were available, we might presume to criticise some details in Mr. Boulenger's "lkeys"; and we cannot conclude without mentioning that the value of the work would have been increased if the dates of presentation of the specimens were added. The work appears singularly free from misprints.

R. L.

\section{THE INTERNAL-COMBUSTION ENGINE.}

Gas Engines. By W. J. Marshall and Captain H. R. Sankey. Pp. xvi+278. (London: Constable and Co., Ltd., I9Ir.) Price 6s. net.

THIS book is the latest addition to Messrs. Con1 stable and Co.'s Westminster series, and is intended to be useful to

" those who, being either purchasers or users of gas engines, wish to know the principles underlying the design or construction and the methods of diagnosing defects when they occur, and the steps to be taken to remedy such defects."

It may fairly be said to have achieved its purpose, and, for the most part, any criticism to which it lays itself open is little more than that to which almost any first edition is liable.

The book (an unusually heavy one to handle for its size) is divided into ten chapters, of which the first three deal with the theory of gas engines and with the Otto and two-stroke cycles of operation. The fourth, fifth, and sixth chapters are concerned with 